\title{
The Nature of HISTORY
}

in Ancient Greece and Rome 


\section{EIDOS | Studies in Classical Kinds}

Thomas G. Rosenmeyer, General Editor 


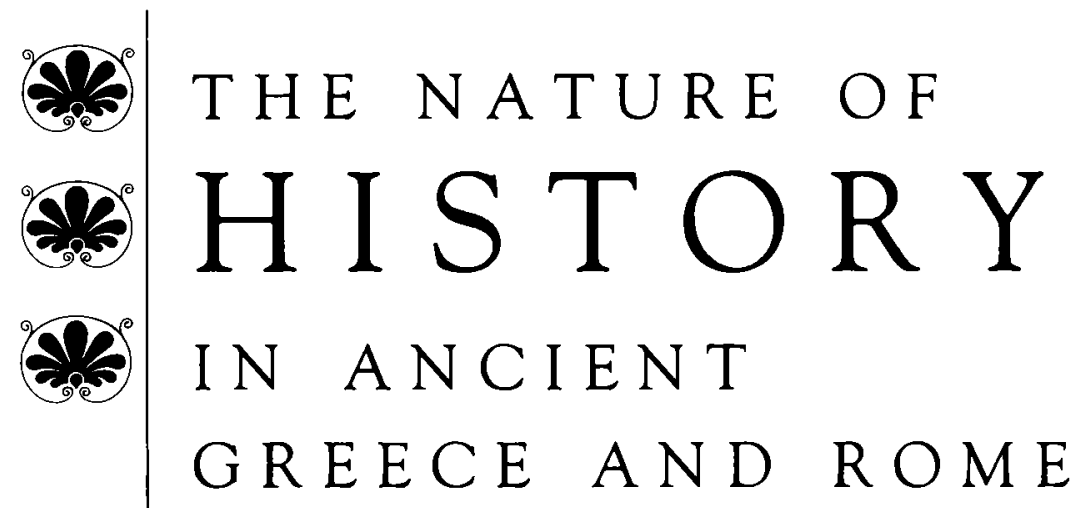

CHARLES WILLIAM FORNARA

University of California Press

Berkeley $\cdot$ Los Angeles $\cdot$ London 
University of California Press

Berkeley and Los Angeles, California

University of California Press, Ltd.

London, England

(C) 1983 by

The Regents of the University of California

Library of Congress Cataloging in Publication Data

Fornara, Charles W.

The nature of history in ancient Greece and Rome.

(Eidos)

Includes index.

1. Greece-Historiography. 2. Rome-Historiography.

3. Historiography-Greece. 4. Historiography-Rome.

I. Title. II. Series: Eidos (University of California

Press)

DE8.F67 $1983 \quad 949.5^{\prime} 0072 \quad 82-21888$

ISBN 0.520-04910-1

Printed in the United States of America

123456789 
For Michael Putnam 
